\title{
The art of strain improvement of industrial lactic acid bacteria without the use of recombinant DNA technology
}

\author{
Patrick MF Derkx , Thomas Janzen, Kim I Sørensen, Jeffrey E Christensen, Birgitte Stuer-Lauridsen, Eric Johansen \\ From 11th International Symposium on Lactic Acid Bacteria \\ Egmond aan Zee, the Netherlands. 31 August - 4 September 2014
}

\begin{abstract}
The food industry is constantly striving to develop new products to fulfil the ever changing demands of consumers and the strict requirements of regulatory agencies. For foods based on microbial fermentation, this pushes the boundaries of microbial performance and requires the constant development of new starter cultures with novel properties. Since the use of ingredients in the food industry is tightly regulated and under close scrutiny by consumers, the use of recombinant DNA technology to improve microbial performance is currently not an option. As a result, the focus for improving strains for microbial fermentation is on classical strain improvement methods. Here we review the use of these techniques to improve the functionality of lactic acid bacteria starter cultures for application in industrial-scale food production. Methods will be described for improving the bacteriophage resistance of specific strains, improving their texture forming ability, increasing their tolerance to stress and modulating both the amount and identity of acids produced during fermentation. In addition, approaches to eliminating undesirable properties will be described. Techniques include random mutagenesis, directed evolution and dominant selection schemes.
\end{abstract}

\section{Introduction}

Lactic acid bacteria (LABs) are industrially important organisms used for the production of dairy products like yoghurt, cheese, buttermilk and kefir. Apart from fermenting milk, LABs are also used to ferment vegetables, meat, fish and cereals. Finally, LABs play an important role in the production of alcoholic beverages [1]. Species used for these applications typically belong to the genera Lactococcus, Streptococcus, Pediococcus, Oenococccus, Leuconostoc or Lactobacillus and have been isolated from natural habitats like plants, or fermented foods like dairy and meat products $[2,3]$. Apart from having a preservative effect by inhibiting the growth of spoilage microorganisms through the production of organic acids and consumption of nutrients, LABs also improve organoleptic properties of the product by producing metabolites that can enhance taste and texture [2]. The global

\footnotetext{
* Correspondence: dkpde@chr-hansen.com Innovation, Chr Hansen A/S, 10-12 Bøge Allé, DK2970, Hørsholm, Denmark
}

dairy industry is constantly exploring new ways to improve products to fulfil consumers' demand for improved taste and texture or the reduction of additives, sugar, fat or overall calorie content. This pushes the boundaries of microbial performance and requires the constant development of new starter cultures with novel properties.

Progress made in the last decade in the field of laboratory automation and high throughput screening of microorganisms has significantly reduced the effort required to screen large collections for specific traits [4]. Wild type strains may have properties unique to the industry, but to fully exploit their potential, specific improvements are often required. In other cases it might be needed to reduce or eliminate an unwanted property. In addition, it can be of interest to improve strains which already have established industrial applicability. Recombinant DNA technology, due to its precision and versatility, would be an ideal technology to use to improve microbial performance were it not for restrictive food legislation 
and consumer acceptance issues for genetically modified food ingredients. Thus, all efforts to improve strains for industrial application are, today, based on natural strategies for strain improvement (i.e. without the use of recombinant DNA technology) such as random mutagenesis, directed evolution and dominant selection.

Random mutagenesis (classical strain improvement) has been used extensively in the food industry $[5,6]$. This approach is based on the introduction of random mutations into the genome of interest, characterization of a large subset of variants, and selection of strains with the desired property for further use. Despite many successes, the method is generally hampered by the fact that, apart from the desired mutation, many unintended mutations which could have a negative impact on performance are introduced [7].

Directed evolution (or adaptive evolution) is a technique in which a strain is slowly adapted to certain growth conditions reflecting an application parameter $[8,9]$. In this case the population is enriched for strains with the desired property but, here too, there is a risk of accumulation of unintended mutations (reviewed by Barrick and Lenski [10]).

Dominant selection is based on designing a selection scheme in which only strains with the desired property can grow [11]. Success of such a method requires considerable insight into microbial physiology. If the selection is powerful enough, strains with single mutations can be obtained without using mutagenic agents.

Furthermore, natural mechanisms like bacteriophage transduction, natural competence and conjugation can be mentioned as additional useful approaches since these are specifically excluded from the European Union's definition of recombinant DNA techniques provided that none of the strains involved are genetically modified organisms [12].

In this review we will illustrate the use of the abovementioned methods with examples from the literature and our own laboratories and elaborate on the importance of natural strain improvement techniques (see Table 1 \& Figure 1 for an overview). Focus will be on Lactococcus, Streptococcus and Lactobacillus primarily used for dairy fermentations.

\section{Improving bacteriophage resistance}

The prevention of bacteriophage attack is one of the most important challenges in dairy fermentations. Although naturally occurring bacteriophage resistance mechanisms are present in LABs, it is necessary to continuously improve bacteriophage resistance due to the high adaptability and diversity of bacteriophages [13,14]. Many bacteriophage infections can be prevented by using a culture replacement or rotation system based on LABs belonging to different bacteriophage sensitivity groups. Here we focus on Lactococcus lactis due to their importance and high frequency of use in dairy fermentations. Several approaches for making bacteriophage resistant mutants of $L$. lactis are described below. These include refinement of traditional methods like the isolation of spontaneous bacteriophage resistant mutants, conjugative transfer of bacteriophage resistance plasmids, as well as a novel approach based on understanding the basic biology of bacteriophage infection.

\section{Bacteriophage receptors}

The Lactococcus PIP protein (Phage Infection Protein) [15], encoded by the pip gene, is the receptor for bacteriophages of the prolate-headed $\mathrm{c} 2$ species and was believed to be used by all c2 bacteriophages [16]. While generating c2-resistant mutants of industrial strains of L. lactis using the pGhost9:ISS1 integration system [17] we found bacteriophage resistant mutants which did not contain an ISS1 integration in the pip gene. Instead, the integration was found to be in the $y j a E$ gene, encoding a protein of unknown function [18]. The yjaE gene shows only $22 \%$ identity to the pip gene and is predicted to encode a putative $\mathrm{ABC}$-2-like protein with six membrane-spanning regions with $\mathrm{N}$ - \& C-terminal phage infection protein domains (IPR017500 and IPR17501) and several extended heptad repeats (TIGR03057). Although yjaE has a domain with high similarity to the pip phage infection domain, the low degree of identity makes it clear that $\mathrm{YjaE}$ is a unique cellular component. Generation of gene disruption mutants confirmed that inactivation of the $y j a E$ gene renders strains completely resistant to a number of bacteriophages of the $\mathrm{c} 2$ species as well as to two bacteriophages of the 936 species (Table 2). Bacteriophages that require YjaE for infection (CHPC3, CHPC24, CHL92, bil67) are not affected by disruption of the pip gene, and bacteriophages which require the PIP protein (CHPC180, c2) can still infect yjaE mutants. Thus, the two best characterized type c2 bacteriophages, c2 and bIL67 [19], use different receptors: $\mathrm{c} 2$ uses PIP and bIL67 uses YjaE.

We isolated spontaneous bacteriophage resistant mutants of five different industrial $L$. lactis strains by challenging with different bacteriophages using the YjaEreceptor and found that all resistant mutants investigated had mutations within the yjaE gene. Out of 21 bacteriophage resistant mutants, 18 strains had single nucleotide changes generating premature stop codons upstream of the membrane-spanning regions and resulting in a truncated protein. The three remaining mutants had deletions within the membrane anchoring region, the promoter region or the external loop. To date, we have not observed bacteriophage using the YjaE-receptor being able to overcome the resistance of $\mathrm{YjaE}$ deficient strains. Importantly, the inactivation of the $y j a E$ gene does not affect the acidification profile of industrial $L$. lactis strains. This method is 
Table 1 Overview of methods described in this review.

\begin{tabular}{|c|c|c|c|c|}
\hline Method used & Advantages & Disadvantages & Topic & Aim \\
\hline \multirow[t]{5}{*}{$\begin{array}{c}\text { Random } \\
\text { mutagenesis }\end{array}$} & $\begin{array}{l}\text { Little knowledge required. } \\
\text { Especially useful for elimination of specific } \\
\text { characteristics where direct selection is not } \\
\text { possible. }\end{array}$ & $\begin{array}{l}\text { Use of dangerous chemicals. } \\
\text { Mutation bias and hot spots. } \\
\text { Second site mutations will be } \\
\text { created. } \\
\text { Requires screening of a large } \\
\text { number of survivors. }\end{array}$ & Pyrimidine auxotrophy & $\begin{array}{l}\text { Bacteriophage } \\
\text { resistance }\end{array}$ \\
\hline & & & $\begin{array}{l}\text { Elimination of antibiotic } \\
\text { resistance }\end{array}$ & $\begin{array}{l}\text { Eliminating } \\
\text { unwanted } \\
\text { property }\end{array}$ \\
\hline & & & Elimination of citrate metabolism & $\begin{array}{l}\text { Eliminating } \\
\text { unwanted } \\
\text { property }\end{array}$ \\
\hline & & & $\begin{array}{l}\text { Urease negative mutants of } S \text {. } \\
\text { thermophilus }\end{array}$ & $\begin{array}{l}\text { Eliminating } \\
\text { unwanted } \\
\text { property }\end{array}$ \\
\hline & & & $\begin{array}{l}\text { Lactobacillus strains with low } \\
\text { post acidification }\end{array}$ & $\begin{array}{l}\text { Improving } \\
\text { product stability }\end{array}$ \\
\hline $\begin{array}{l}\text { Directed } \\
\text { evolution }\end{array}$ & $\begin{array}{l}\text { Little knowledge required. } \\
\text { Especially useful for complex phenotypes. } \\
\text { Mutagens normally not required. }\end{array}$ & $\begin{array}{l}\text { Multiple mutations may occur. } \\
\text { May require complex } \\
\text { experimental setups. } \\
\text { Slow process requiring long } \\
\text { time frames. } \\
\text { Selection is at population level, } \\
\text { isolated strains must be } \\
\text { characterized. }\end{array}$ & $\begin{array}{l}\text { Increasing the growth yield } \\
\text { during fermentation }\end{array}$ & $\begin{array}{l}\text { Increased } \\
\text { efficiency in } \\
\text { culture production }\end{array}$ \\
\hline \multirow[t]{8}{*}{$\begin{array}{l}\text { Dominant } \\
\text { selection }\end{array}$} & $\begin{array}{l}\text { Mutagens not required. } \\
\text { Often results in a single mutation. }\end{array}$ & $\begin{array}{l}\text { Requires considerable insight } \\
\text { into physiology of the cell. } \\
\text { Analogues may be toxic to } \\
\text { humans. }\end{array}$ & Bacteriophage receptors & $\begin{array}{l}\text { Bacteriophage } \\
\text { resistance }\end{array}$ \\
\hline & & & Conjugation & $\begin{array}{l}\text { Bacteriophage } \\
\text { resistance }\end{array}$ \\
\hline & & & Modifying bacterial cell surfaces & Improving texture \\
\hline & & & $\begin{array}{l}\text { Optimizing the metabolic } \\
\text { pathway of EPS }\end{array}$ & Improving texture \\
\hline & & & Bacteriophage resistant mutants & Improving texture \\
\hline & & & $\begin{array}{l}\text { Lactobacillus strains with } \\
\text { improved ethanol or bile } \\
\text { tolerance }\end{array}$ & $\begin{array}{l}\text { Improving survival } \\
\text { and efficacy }\end{array}$ \\
\hline & & & Lb. helveticus producing succinate & Improving flavor \\
\hline & & & $\begin{array}{l}\text { Altering acidification properties } \\
\text { by adapting the carbohydrate } \\
\text { metabolism }\end{array}$ & $\begin{array}{l}\text { Overcoming effect } \\
\text { of a mutation }\end{array}$ \\
\hline $\begin{array}{l}\text { Recombinant } \\
\text { DNA } \\
\text { technology }\end{array}$ & Extremely accurate targeted methods. & $\begin{array}{l}\text { Consumer acceptance. } \\
\text { Regulatory approval. } \\
\text { Can be difficult to apply to } \\
\text { industrial strains. }\end{array}$ & Potentially all of the above & $\begin{array}{l}\text { Potentially all of } \\
\text { the above }\end{array}$ \\
\hline
\end{tabular}

thus ideal for generating new bacteriophage resistant starter cultures without compromising the performance of the culture during application [18].

\section{Conjugation}

Improvement of bacteriophage resistance by conjugation is frequently described in the literature, especially for L. lactis, where many bacteriophage resistance systems are localized on plasmids [20]. The bacteriophage resistance of L. lactis CHCC1915 and CHCC1916 was improved by conjugative transfer of the bacteriophage resistance plasmid pCI1750 from L. lactis UC653 harboring the resistance system AbiG [21]. This abortive infection (Abi) mechanism is encoded by two genes, $a b i G i$ and abiGii, conferring resistance to bacteriophages of the 936 species, and partial resistance to c2 species bacteriophages [22]. For mating experiments, a lactose negative derivative (MG1363 containing pCI1750) was used as plasmid donor, and transconjugants were selected by challenging with bacteriophages 


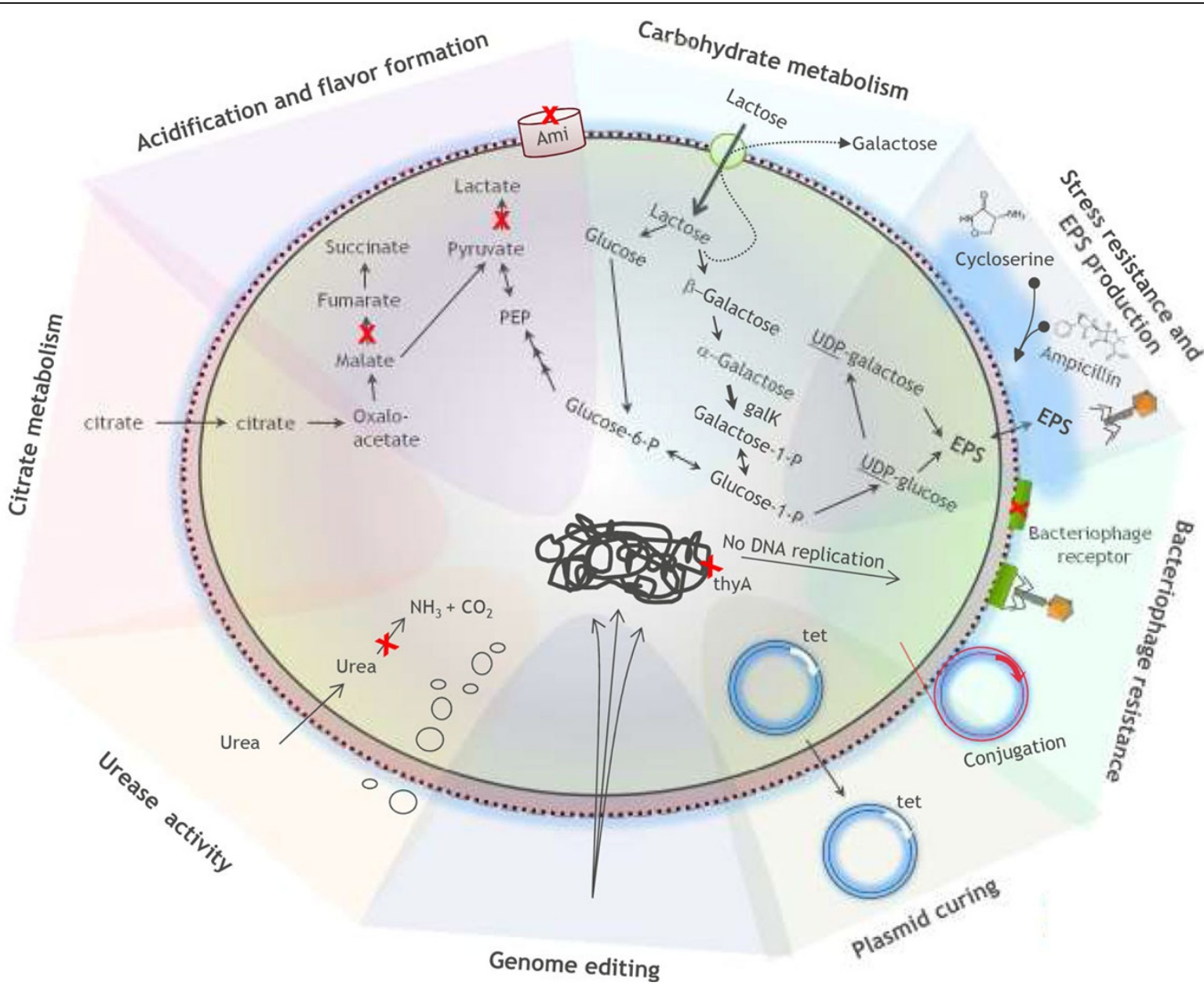

Figure 1 Schematic representation of various classical strain improvement targets of LABs. A cross (X) highlights the position of mutations or effect of mutations as described in the text.

Table 2 Bacteriophage sensitivity of yjaE and pip mutants.

\begin{tabular}{|c|c|c|c|c|c|c|c|c|}
\hline & Phage species & IL1403 & $\begin{array}{c}\text { IL1403 } \\
\Delta y j a E \\
\text { GMO }\end{array}$ & $\begin{array}{c}\text { IL1403 } \\
\text { AyjaE } \\
\text { spont. }\end{array}$ & $\begin{array}{c}\text { IL1403 } \\
\Delta \text { pip } \\
\text { GMO }\end{array}$ & $\begin{array}{l}\text { CHCC } \\
7552\end{array}$ & $\begin{array}{l}\text { CHCC } \\
7552 \\
\Delta y j a E \\
\text { GMO }\end{array}$ & $\begin{array}{c}\text { CHCC } \\
7552 \\
\Delta y j a E \\
\text { spont. }\end{array}$ \\
\hline CHPC3 & $c 2$ & + & - & - & + & + & - & - \\
\hline CHPC24 & $c 2$ & + & - & - & + & + & - & - \\
\hline CHPC180 & c2 & + & + & + & - & - & - & - \\
\hline CHL92 & c2 & + & - & - & + & + & - & - \\
\hline blL67 & $c 2$ & + & - & - & + & - & - & - \\
\hline c2 & $c 2$ & + & + & + & - & - & - & - \\
\hline CHPC234 & 936 & - & - & - & - & + & - & - \\
\hline
\end{tabular}

Legend table 2:

+ : lysis by bacteriophage; - : no lysis by bacteriophage

GMO: produced with recombinant DNA technology

spont.: spontaneous mutant generated by challenge with bacteriophage requiring YjaE (e.g. CHPC24).

inhibiting the recipient followed by plating on lactose indicator agar plates. Transconjugants of CHCC1915 and CHCC1916 have been on the market for more than
20 years and are still performing well, although several bacteriophage have been isolated which are unaffected by the AbiG resistance system. 


\section{Pyrimidine auxotrophy}

In contrast to the previous examples where bacteriophage resistance is not established for every bacteriophage attacking a certain strain, it is possible to develop completely resistant mutants by abolishing bacteriophage DNA replication [23,24]. Thymidylate synthase, encoded by the thy $A$ gene, is essential for the de novo synthesis of dTTP. Since milk is devoid of thymidine, replication of DNA, including DNA from an infecting bacteriophage, is abolished in thyA mutants. MBP71, a thyA mutant of L. lactis $\mathrm{CHCC} 373$ with a 42-bp deletion at the beginning of the thy $A$ gene shows complete resistance towards nine bacteriophages from the 936 and P335 species. Because thy $A$ mutants are still able to synthesize RNA and thereby also proteins, mutants are still metabolically active. Since cell division does not occur, it is necessary to increase the inoculation rate to reach an acidification activity similar to that of the wild type strain [23]. MBP71 was created using recombinant DNA technology and exclusively used for proof-of-concept. Mutagenesis and screening for pyrimidine auxotrophy has subsequently been used to obtain variants of industrial strains of $L$. lactis and S. thermophilus suitable for inclusion in starter cultures. No bacteriophage variants that overcome this resistance mechanism have been discovered to date.

\section{Improving texture of fermented milk}

Pectins and starch are often used to create the desired texture in fermented milk products. These additives can, however, be rendered unnecessary through development of LABs which create the desired texture. Especially the production of extracellular polysaccharides (EPS) has been in focus since EPS is known to contribute to the texture of fermented milks [25]. Here we describe several natural strain improvement methods to improve the ability of LABs to texturize fermented milk.

\section{Modifying bacterial cell surfaces}

The bacterial cell surface is in direct contact with the external environment and is expected to be involved in binding of environmental components and formation of texture in milk during fermentation. EPS production has previously been found to be highly strain dependent and strongly correlated to the Streptococcus thermophilus genotype and especially to the genetic content of the eps gene cluster [26]. Texture formation is, apart from EPS [27], also affected by other bacterial cell surface components $[28,29]$. The structure and function of the cell surface of lactic acid bacteria has recently been reviewed [30].

To further exploit the role of the cell surface in the formation of texture in fermented milk, we applied a dominant selection strategy to isolate mutants with cell surface alterations. Selection was based on resistance to compounds interfering with the biosynthesis of cell surface components; viz. D-cycloserine (D-4-amino-isoxazolidone) and ampicillin. D-cycloserine is an antibiotic which inhibits enzymes involved in D-alanine metabolism and can cause cell lysis [31,32]. Ampicillin is an antibiotic which inhibits the transpeptidase responsible for crosslinking peptidoglycan and can also cause cell lysis [33]. Mutants of Lactobacillus delbrueckii subsp. bulgaricus which are resistant to either D-cycloserine or ampicillin are readily obtained. Some of these show reduced whey syneresis after acidification of milk and improved texturizing properties as determined by rheology measurement [14]. Preliminary experiments show that these mutants have changes in their cell surfaces which affect their interactions with the external environment.

\section{Optimizing the metabolic pathway of EPS}

Most strains of $S$. thermophilus are unable to grow on galactose as sole carbon source in spite of the presence of intact genes encoding the required enzymes. Increased EPS production in $S$. thermophilus was observed following enhancement of the activity of enzymes in the galactose metabolic pathway (e.g. phosphoglucomutase and glucose-1-phosphate uridylyltransferase) by genetic manipulation $[34,35]$. Also, production of EPS by ropy $S$. thermophilus strains was increased through genetically targeted enhancement of galactokinase activity. However, combining such a mutant with a $L b$. delbrueckii subsp. bulgaricus strain for yoghurt production did not result in significant overproduction of EPS, and the texturizing properties of the yoghurt were not improved [36]. Improvement of the rheological parameters of yoghurt by modifying enzymatic activity in the galactose metabolic pathway without the use of recombinant DNA techniques has not been reported.

S. thermophilus CHCC6008 is used extensively in the dairy industry because of its ability to texturize fermented milk. Strain CHCC11379 was isolated as a spontaneous galactose positive mutant of $\mathrm{CHCC} 6008$ as described in the section describing dominant selection. The ability of CHCC11379 to texturize fermented milk was increased by $10 \%$, measured as shear stress, compared to its parent CHCC6008 [28]. Analysis of the galactose operon of CHCC11379 revealed a $\mathrm{G}$ to A mutation within the -10 position of the galK promoter resulting in a perfect “TATAAT" Pribnow box [37]. This optimized Pribnow box increased transcription of the genes from the galactose operon (galK, galT, galE, and galM) 2.5 to 3.7-fold. The amount of excreted EPS during milk fermentation was, however, not significantly increased for CHCC11379 suggesting that the ability to ferment galactose leads to a change in composition of the EPS rather than to an increase in the quantity. In contrast to the results from Robitaille et al. [36], viscosity and shear stress were increased when $\mathrm{CHCC} 11379$ was used in a yoghurt 
culture together with an EPS positive Lb. delbrueckii ssp. bulgaricus strain. This indicates that texture in milk is not determined solely by the amount of excreted EPS; EPS structure and the interaction between different EPS types also play a role.

\section{Bacteriophage resistant mutants}

Capsular polysaccharides (CPS) can provide a protective barrier against bacteriophage infection although it was reported that it was not possible, so far, to increase EPS production using bacteriophages as selective agent [38]. Nevertheless, we speculated that selecting for bacteriophage resistance in CPS positive and, at the same time, EPS excreting $S$. thermophilus strains could result in mutants with increased CPS production and improved texture. S. thermophilus CHCC11977 was isolated as a bacteriophage-resistant mutant of a galactosepositive $S$. thermophilus strain, and its texturizing properties in milk, measured as shear stress and viscosity, were improved by $20 \%$ compared to its parent [39]. The amount of excreted EPS was also increased by $20 \%$ in CHCC11977.

\section{Removal of undesirable traits}

LABs are used in food fermentations due to their many desirable properties. However, certain properties may be undesired in the food chain while others might be undesirable under certain conditions. Elimination of an undesirable property will be an improvement of the industrial properties of a strain.

\section{Elimination of antibiotic resistance}

The increasing resistance of pathogenic bacteria to commonly used antibiotics is a growing threat to public health [40]. Resistance can either be acquired by mutation or by the transfer of antibiotic resistance genes from other bacteria. Bacteria intentionally added to the food supply should not contain transmissible antibiotic resistance genes. For this reason, all strains which are intended for use in the food chain are tested genotypically [41] and phenotypically [4] for antibiotic resistances not normally observed in the relevant species. Strains with atypical patterns are further characterized and those with potentially transmissible antibiotic resistance genes are either eliminated from further product development or measures are taken to eliminate or inactivate the undesired antibiotic resistance determinant.

Transmissible antibiotic resistance genes are often located on transposable elements or plasmids. While this increases the likelihood of transfer, it also simplifies the elimination process since these elements are often genetically unstable.

Lb. crispatus CHCC3692 contains an erm(B) gene encoding high level resistance to erythromycin on a 3.2 $\mathrm{kb}$ transposon. Heat shock treatment at $60^{\circ} \mathrm{C}$ was found to induce the expression of a transposase and resulted in excision of $\operatorname{erm}(\mathrm{B})$ from the chromosome [42].

Plasmids encoding antibiotic resistance genes are common in lactic acid bacteria and especially in Lactobacillus isolates. A number of different methods exist for elimination of a plasmid from a strain; the optimal method being highly strain dependent [43]. Acridine orange and mitomycin- $\mathrm{C}$ were used to eliminate an erm gene from a strain of $L b$. fermentum [44] while novobiocin was used to eliminate a tet $(\mathrm{M})$ and a tet(S) gene, respectively, from two different strains of $L b$. plantarum $[45,46]$. Protoplast formation and regeneration was the only method found suitable to remove two plasmids encoding tetracycline resistance (tet (W)) and lincosamide resistance $(\ln u(\mathrm{~A}))$ from a commercially used probiotic $L b$. reuteri strain [47].

In some cases, it might be of interest to eliminate or inactivate antibiotic resistance genes which have not been shown to be transmissible and which do not reside on a transposon or plasmid. An example of this is the tet $(\mathrm{W})$ gene responsible for tetracycline resistance in all known members of Bifidobacterium animalis subsp. lactis [48]. Ultraviolet light mutagenesis of cells grown in the presence of ethidium bromide was used to obtain tetracycline-sensitive mutants of strains bearing a chromosomal tet(W) gene. For all mutants tested, it was possible to obtain strains with mutations in the tet $(\mathrm{W})$ gene $[48,49]$.

\section{Elimination of citrate metabolism}

The ability to catabolize citrate to acetate, carbon dioxide and pyruvate is present in many LABs, and citrate utilization is often associated with the production of acetoin and diacetyl [50]. While these compounds improve the properties of some fermented products (e.g. buttermilk and some cheeses), excessive production is unwanted in others (e.g. wine and cottage cheese).

During malolactic fermentation in wine by Oenococcus oeni, the accumulation of acetate and diacetyl resulting from citrate metabolism can negatively impact the sensory properties [51]. Random mutagenesis was used to eliminate citrate utilization in a commercial $O$. oeni strain. The resulting variant contains a nonsense mutation in the citrate transporter gene [4]. The ability to utilize citrate in O. oeni is plasmid encoded [52] suggesting plasmid curing as an alternative approach as described in the section describing random mutagenesis.

The ability of L. lactis subsp. lactis biovar diacetylactis to utilize citrate is also plasmid encoded [53]. This feature is important for the production of flavor compounds and carbon dioxide in cheeses like Danbo, Havarti and Gouda, but these compounds are unwanted for the production of cottage cheese (see also the section describing random mutagenesis). Elimination of the 
citrate plasmid in L. lactis subsp. lactis biovar diacetylactis can be achieved by heat-shock or treatment with novobiocin resulting in strains useful for cottage cheese production [54].

\section{Urease negative mutants of $S$. thermophilus}

Traditionally, cottage cheese is made by fermenting milk with L. lactis [55]. Recently, the use of S. thermophilus as a starter cultures for cottage cheese has gained popularity due to its faster acidification rate resulting in a faster production process in the dairy and a significant gain in capacity.

S. thermophilus possesses amidohydrolase activity (urease; EC. 3.5.1.5) which converts urea into ammonia and carbon dioxide [56]. The carbon dioxide is incorporated into the cheese curd particles making them float which hinders whey removal and results in a loss of cheese mass. To tackle this problem a urease negative mutant of S. thermophilus CHCC4895 was isolated by random mutagenesis. Screening was done on plates containing a $\mathrm{pH}$ indicator; mutants devoid of urease activity lack buffering capacity due to reduced ammonia production. Mutant $\mathrm{CHCC} 12406$ did not show the typical pH increase when grown in milk with added urea, verifying the urease negative phenotype (Figure 2), and ammonia production was reduced by ca. $90 \%$. Cheese trials made with $\mathrm{CHCC} 12406$ showed reduced floating of cheese curd particles (Figure 3) confirming the role of the $S$. thermophilus urease activity in the "floating curd" phenomenon and the possible use of cheese cultures based on urease negative mutants as a solution [57].

\section{Improving stress tolerance}

Industrial production of starter cultures and their subsequent use in industrial processes for the production of fermented food subject the LABs to a large variety of stresses. For probiotic LABs, there is the additional stress associated with life in the human gastrointestinal tract. There is a strong interest in increasing the intrinsic tolerance of LABs to these stress factors.

\section{Lactobacillus strains with improved ethanol or bile tolerance}

Malolactic fermentation mediated by LABs is important for flavor development in a number of wine varieties. Ethanol levels in wine have been increasing in recent years, possibly as a consequence of higher sugar levels in grapes caused by warmer growing seasons, putting stress on the malolactic bacteria. Consequently, development of malolactic bacteria that are resistant to higher levels of alcohol would be useful in the wine industry. Adaptation is often used to make microorganisms more tolerant to environmental stresses but this effect is only temporary. Resistance, on the other hand, is a permanent property which is typically acquired through genetic change. During the characterization of Lb. plantarum D-cycloserine resistant mutants, we discovered a number of unexpected phenotypes. For example, a number of the mutants are significantly more tolerant to ethanol than the parent strain. It was postulated that changes in the cell surface architecture result in reduced access of ethanol to the cell membrane thereby resulting in increased ethanol tolerance [58].

When efficacy of a probiotic strain is directly related to viability in the gastrointestinal tract, strain improvement can include increasing survival following exposure to gastric acid and bile. Multiple mechanisms are proposed to account for increased resistance to bile including efflux of bile acids/salts, modified sugar metabolism, and cell membrane or cell wall composition modification [59-61]. We also tested mutants of potentially probiotic Lactobacillus strains, selected using D-cycloserine resistance as described previously, for enhancement of bile tolerance. Some D-cycloserine resistant mutants showed higher survival rates than the parental strain when exposed to a bile shock and others demonstrated additional useful

\section{A}

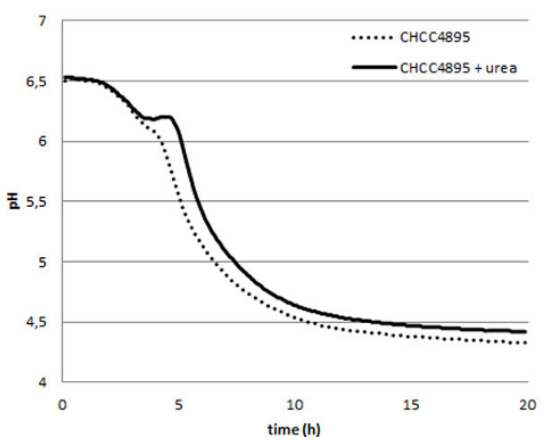

B

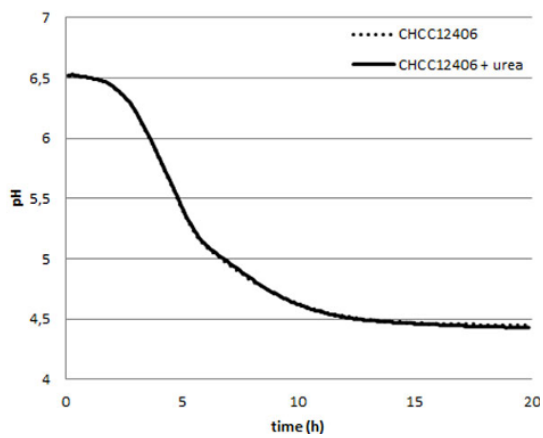

Figure 2 Acidification curves (dashed line) of S. thermophilus CHCC4895 (A) and its urease mutant CHCC12046 (B) and the effect of the addition of urea (solid line) 


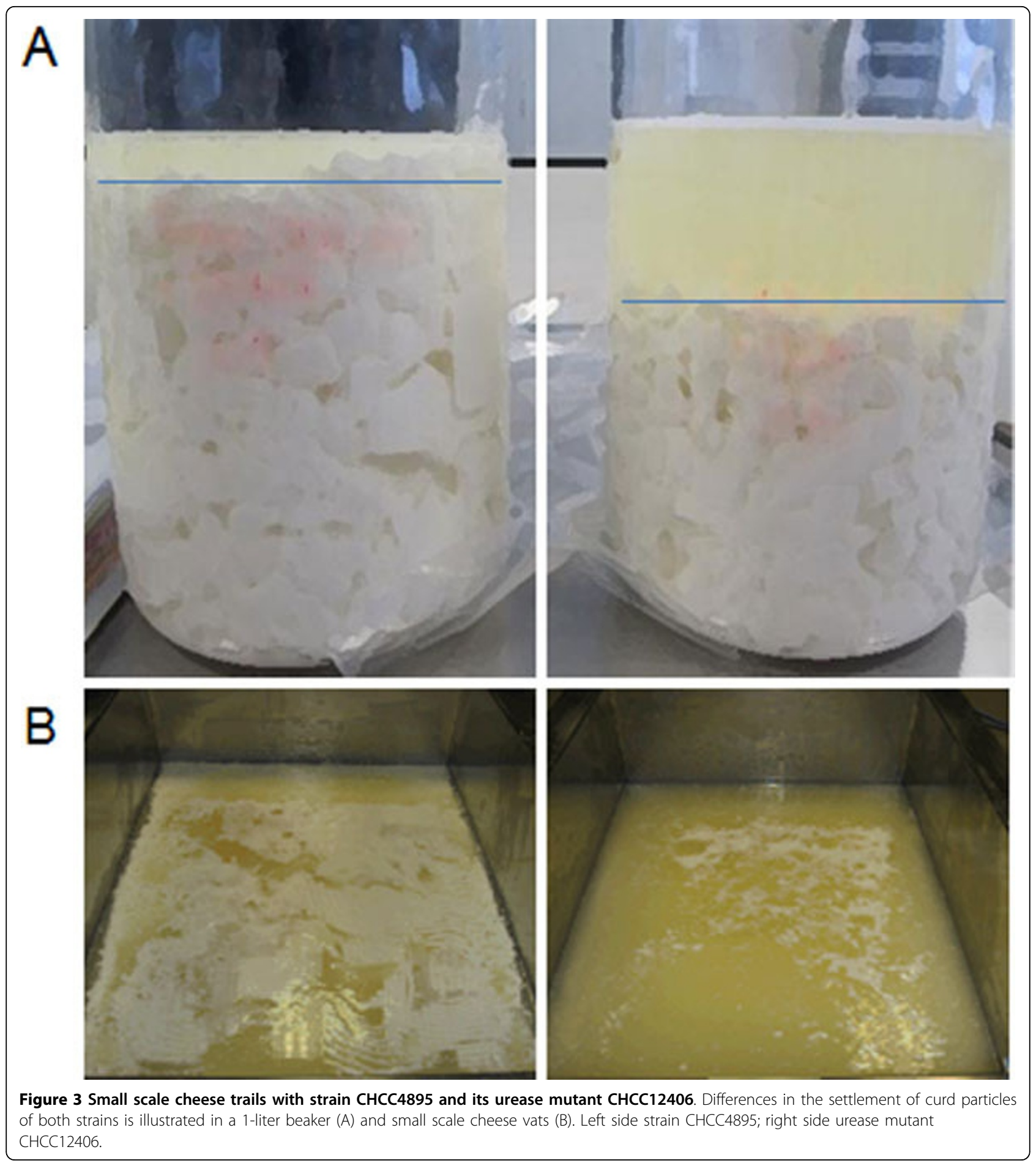

characteristics such as improved survival following gastric acid shock or desiccation. Genome sequence analysis showed unique mutations in each strain, though not all obviously related to D-cycloserine resistance. Importantly, for several highly bile tolerant isolates, there were no detectable changes in other in vitro characteristics used to evaluate probiotic potential, including adherence to mucus and stimulation of dendritic cell cytokine secretion.

\section{Acid production}

The specific acids and the quantities produced by lactic acid bacteria in fermented products have major 
consequences on the properties of the final product. Acid production by LABs is therefore a desirable property to modulate and control.

\section{Lactobacillus strains with low post acidification}

Strains of Lb. delbrueckii subsp. bulgaricus and S. thermophilus are essential culture components in the production of yoghurt. While many strains of Lb. delbrueckii subsp. bulgaricus display excellent texturizing properties, they might not be suitable for mild yoghurt applications due to the continued production of lactic acid during the shelf life of the yoghurt, a process referred to as "postacidification". Current consumer preferences for yoghurt are for mild products with low post-acidification and a high texture.

A random mutagenesis and screening strategy was developed [62] to generate $L b$. delbrueckii subsp. bulgaricus strains that combine excellent texturizing properties with low-post acidification. A strain with suitable texturizing properties but high post-acidification was treated with a mild mutagen and the resulting strain library screened in milk in microtiter plates using a colorimetric method for $\mathrm{pH}$ determination [4]. Mutants showing a higher end-pH than the mother strain were subsequently screened to find those which retained the desirable texturizing properties. This led to the isolation of a unique strain of Lb. delbrueckii subsp. bulgaricus, CHCC10019, which is able to acidify and texturize milk under industrially relevant conditions but is characterized by low post acidification. When using $\mathrm{CHCC} 10019$, the $\mathrm{pH}$ of the fermented milk drops by less than $0.20 \mathrm{pH}$ units over 7 days at $8^{\circ} \mathrm{C}$.

In another approach to obtain improved strains with reduced post-acidification the importance of the oligopeptide transport for growth fitness of $S$. thermophilus in milk was explored. The oligopeptide transport system in $S$. thermophilus consists of a seven proteins (AmiA1, AmiA2, AmiA3, AmiC, AmiD, AmiE and AmiF) and mutants exhibiting an altered oligopeptide transport system were found to have a reduced acidification rate [63]. The toxic oligopeptide analog aminopterine is transported into the cell by the Ami system. Accordingly, Garault et al. isolated Ami-deficient mutants with reduced post-acidification in milk by selecting for mutants that were resistant to this analog [64].

\section{Altering acidification properties by adapting carbohydrate metabolism}

When grown in milk, the majority of $S$. thermophilus strains take up lactose and excrete galactose via the galactose-lactose antiporter [65]. In mozzarella cheese this excreted galactose can lead to "browning" upon heating of the cheese. This is ascribed to the Maillard reaction, where galactose, a reducing sugar, reacts with amino groups from amino acids. In addition, excess free galactose can lead to post acidification problems and imbalance in the cheese flora due to growth of resident lactic acid bacteria. Galactose positive wild type strains or galactose fermenting mutants are therefore interesting, especially for the purpose of reducing browning in pizza cheese.

Most strains of $S$. thermophilus are unable to grow on galactose as sole carbon source; those that do grow use the Leloir pathway (Figure 4A). Nearly all strains contain the gal genes, but naturally occurring mutations in the galK promoter result in poor expression [66]. Screening 49 strains revealed only eight galactose fermenters [67] while we found 38 out of 247 S. thermophilus strains screened from our culture collection to have this capability. Since most strains do contain intact gal genes, it should be possible to isolate galactose positive variants from them. Mutants can be selected on M17 plates with galactose as sole carbon source and characterized by DNA sequencing. For example, the mutant mentioned in the section describing the optimization of the metabolic pathway of EPS has a mutation in the promoter region upstream of galK leading to increased expression of the gal genes. Similarly, strain $\mathrm{CHCC} 14993$, derived from the fast acidifying strain CHCC4323, has a $\mathrm{G}$ to A transition resulting in an improved Pribnow box 'TACAAT' (Figure 4B). This single nucleotide exchange enables $\mathrm{CHCC} 14993$ to grow on galactose and results in an $11 \%(\mathrm{w} / \mathrm{v})$ reduction in excreted galactose in milk fermented with this strain.

\section{Increasing the growth yield during fermentation}

When LABs are grown in a batch culture, cells with the fastest growth rate dominate, often at the expense of biomass yield [68]. This is of concern to the starter culture industry as efficiency in the factory is dependent on the production of the maximum amount of biomass at the lowest cost [69]. Using an elegant emulsion system, it was possible to obtain L. lactis mutants with an increased growth yield [68] by eliminating the competitive advantage rapid growth gives in a liquid culture. The yield improvement occurred via mutations which divert the metabolism from lactate production towards mixed acid fermentation. Because these mutants cannot ferment lactose and produce reduced levels of lactate, they are not particularly useful for the dairy industry. They do, however, illustrate very nicely the tradeoff between growth rate and biomass yield that occurs in bacteria and suggest methods for changing the specific acids produced by a strain.

\section{Lactobacillus helveticus producing succinate}

A variety of chemical analogues have been used to isolate mutants of Lactobacillus with improved flavor formation. One analogue, 3,4-dehydroproline, was expected to 


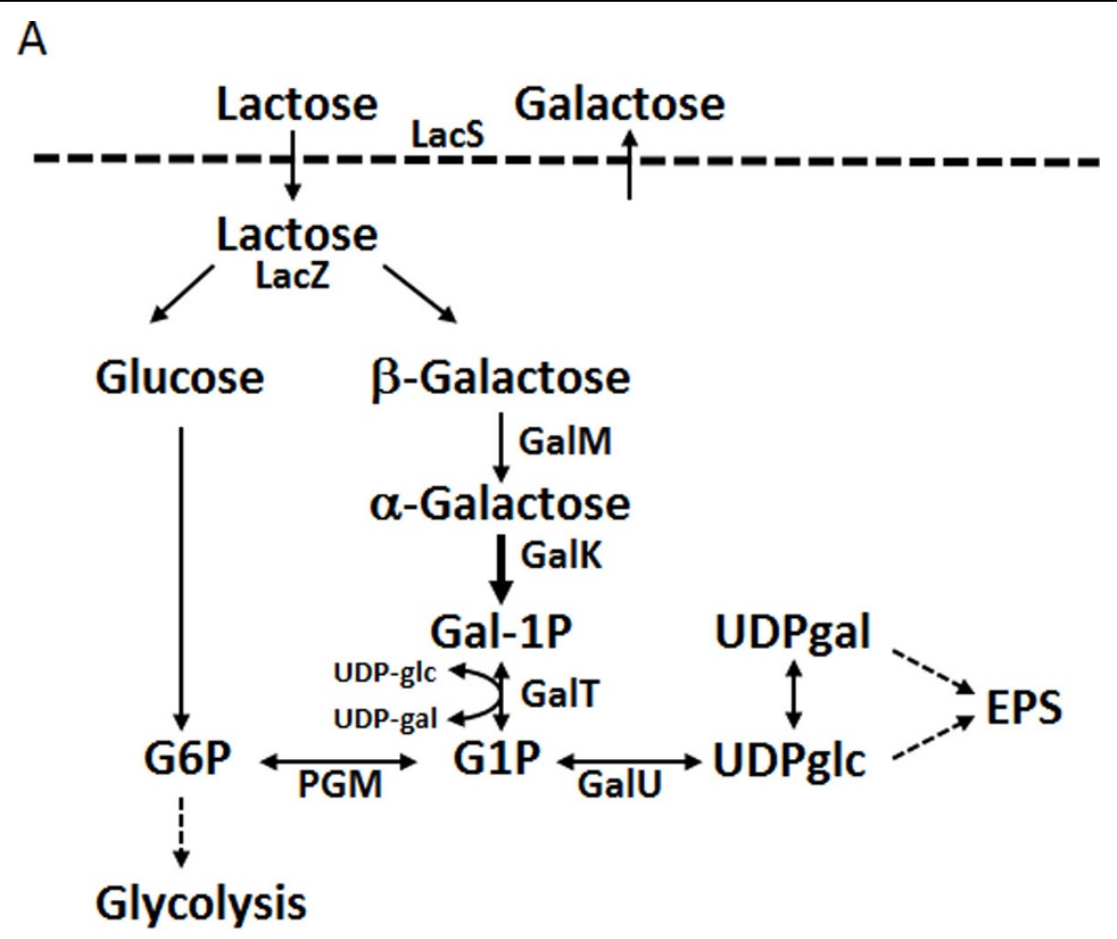

B

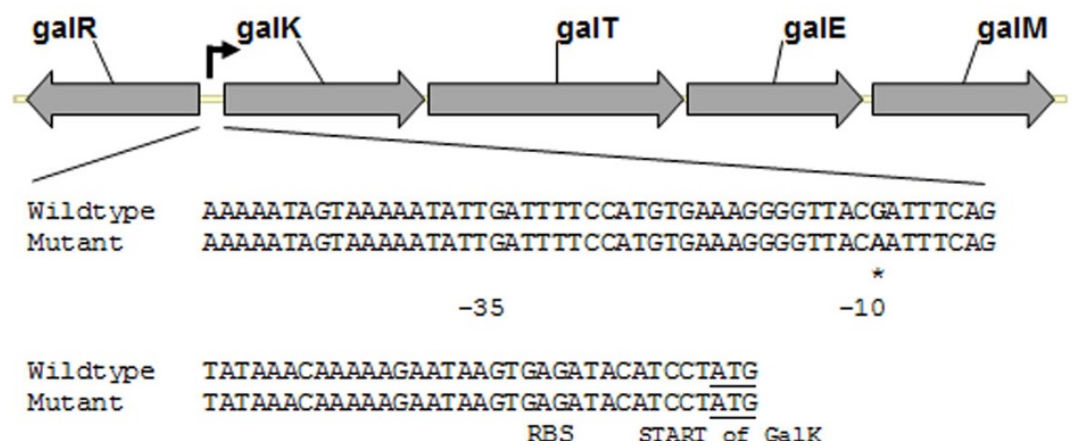

Figure 4 Galactose and lactose metabolism in S. thermophilus, reproduced from Johansen et al. [3](A). Abbreviations: LacS, lactose transporter; LacZ, $\beta$-galactosidase; GlcK, glucose kinase; GalM, mutarotase; GalK, galactokinase; PGM, $\alpha$-phosphoglucomutase; GalT, galactose 1-phosphate udridyltransferase; GalE, UDP glucose 4-epimerase; GalU, UDP glucose pyrophosphorylase; gal1P, galactose-1-phosphate; g1p, glucose-1-phosphate; g6p, glucose-6-phosphate; UDP-glu, UDP-glucose; and UDP-gal, UDP-galactose. (B) The promoter region of the galactose operon; the mutation in the Pribnow box of the mutant strain in bold and marked $\left(^{*}\right)$. The enhanced expression of galK is indicated by a thickened arrow in the pathway and an arrow in the promoter region of the operon.

generate mutants with altered proline and glutamate metabolism in Lb. helveticus. However, when the mutants were characterized, one mutant showed a biphasic acidification of milk and was found to be unable to produce succinate. Genome sequencing revealed a single mutation; it was in an L-lactate dehydrogenase (EC 1.1.1.27; lhe_1813). This finding is consistent with the deviation in acidification pattern but does not readily explain the lacking succinate production. Perhaps the L-lactate dehydrogenase also serves as a malate dehydrogenase. A strain defective in malate dehydrogenase will not produce fumarate and consequently no succinate. However, the isolation of a lactate/malate dehydrogenase mutant using 3,4-dehydroproline was not expected and cannot be readily explained. This illustrates an added benefit of direct selection methods and the use of analogs: surprising observations might lead to new insight into the metabolism of LABs.

\section{Summary and future perspectives}

There is a constant need for new strains for inclusion in starter cultures for the food fermentation industry. New 
strains can either come from screening of wild-type strains from natural sources as described by Johansen et al. [4] or improvement of existing strains as described herein. Many industrially relevant properties can be addressed by these techniques. These include: enhancement of bacteriophage resistance; improvement of the texturizing capability of strains for yoghurt production; elimination of traits undesirable in any food fermentation; elimination of traits undesirable in specific food fermentations; improvement of stress tolerance; and modulation of both the specific acids produced during fermentation as well as the amounts produced. Classical strain improvement can be combined with natural methods of gene transfer like conjugation, transduction and natural transformation to create industrial strains with improved properties in a variety of genetic backgrounds.

An alternative approach is strain improvement using established techniques of recombinant DNA technology. A large number of methods have been developed to create genetically modified organisms which fulfil a published definition of 'food-grade' [69,70]. These are not currently used for the direct development of industrial starter cultures due to concerns over consumer acceptance and regulatory approval. Recombinant DNA technology is, however, routinely used in research laboratories for proofof-concept and subsequently followed up by the development of similar strains created through the use of classical strain improvement. The advantages and disadvantages of the various methods of strain improvement are described in Table 1.

Recent advances in the field of genome editing may provide additional ways of improving strain performance. Technologies like recombineering [71] and use of the CRISPR-Cas9 system [72] allow for precise modification, at the single nucleotide level, in a genome of interest. This allows the production of strains which will be totally indistinguishable from strains produced by classical strain improvement. This high level of specificity in genome editing will require a reassessment of not only the definition of a genetically modified organism but also the reasons behind discriminating strains based on the methods used to develop them.

\section{List of abbreviations used \\ Abi: abortive infection; CPS: Capsular polysaccharide; EPS: Extracellular polysaccharide; GMO: Genetically modified organism; IS: Insertion sequence; L.: Lactococcus; LAB: Lactic acid bacteria; Lb.: Lactobacillus; O.: Oenococcus; PIP: Phage infection protein; S.: Streptococcus.}

\section{Competing interests}

All authors are employed by Chr. Hansen A/S.

\section{Acknowledgements}

The authors thank Mimi Birkelund, Thomas Bovbjerg, Morten Carlson, Ditte Christiansen, Mette Pia Junge, Annette Kibenich, Elahe Moghadam, Jannie
Schnabl and Per Strøman for technical assistance and Ana Rute Neves for critically reading the manuscript.

\section{Declarations}

This article has been published as part of Microbial Cell Factories Volume 13 Supplement 1, 2014: Proceedings of the 11th International Symposium on Lactic Acid Bacteria. The full contents of the supplement are available online at http://www.microbialcellfactories.com/supplements/13/S1. Publication charges for this supplement were funded by the Stichting Symposium on Lactic Acid Bacteria. The articles have undergone the journal's standard peer review process for supplements. EJ is employed by Chr Hansen A/S, is a shareholder in Chr Hansen A/S; and acts as an editor for the supplement but was not involved in the peer review process of this article. EJ has applied for patents relating to the content of this article which he did not edit but which forms part of this supplement. MK is an employee of Nizo. The other Supplement Editors declare that they have no competing interests.

Published: 29 August 2014

\section{References}

1. Leroy F, De Vuyst L: Lactic acid bacteria as functional starter cultures for the food fermentation industry. Trends Food Sci Technol 2004, 15:67-75.

2. Adimpong DB, Nielsen DS, Sørensen Kl, Derkx PMF, Jespersen L: Genotypic characterization and safety assessment of lactic acid bacteria from indigenous African fermented food products. BMC Microbiol 2012, 12:75.

3. El-Shafei HA, Abd-El-Sabour H, Ibrahim N, Mostafa YA: Isolation, screening and characterization of bacteriocin-producing lactic acid bacteria isolated from traditional fermented food. Microbiol Res 2000, 154:321-31.

4. Johansen E, Øregaard G, Sørensen Kl, Derkx PMF: Modern approaches for isolation, selection and improvement of bacterial strains for fermentation applications. In Advances in fermented foods and beverages: Improving quality, technologies and health benefits. Cambridge, UK: Woodhead Publishing Ltd;Holzapfel W 2014.

5. Margolles A, Sanchez B: Selection of a Bifidobacterium animalis subsp. lactis strain with a decreased ability to produce acetic acid. Appl Environ Microbiol 2012, 78:3338-3342.

6. Saarela M, Alakomi HL, Matto J, Ahonen AM, Puhakka A, Tynkkynen S: Improving the storage stability of Bifidobacterium breve in low $\mathrm{pH}$ fruit juice. Int J Food Microbiol 2011, 149:106-110.

7. Unpublished data from our laboratories based on determining the genome sequence of a number of mutants and their respective parent strains.

8. Lapierre L, Mollet B, Germond JE: Regulation and adaptive evolution of lactose operon expression in Lactobacillus delbrueckii. J Bact 2002, 184:928-935.

9. MacLean CR, Torres-Barceló C, Moxon R: Evaluating evolutionary models of stress-induced mutagenesis in bacteria. Nature Reviews Genetics 2013 14:221-227.

10. Barrick JE, Lenski RE: Genome dynamics during experimental evolution. Nat Rev Genet 2013, 14:827-839.

11. Kibenich A, Sørensen $K$, and Johansen E: Texturizing lactic acid bacteria strains 2012, International Patent Application WO/2012/052557.

12. Pedersen $M B$, Iversen $S L$, Sørensen $K l$, Johansen $E:$ The long and winding road from the research laboratory to industrial applications of lactic acid bacteria. FEMS Microbiol Rev 2005, 29:611-24.

13. Sturino JM, Klaenhammer TR: Bacteriophage defense systems and strategies for lactic acid bacteria. Adv Appl Microbiol 2004, 56:331-78.

14. Labrie SJ, Samson JE, Moineau S: Bacteriophage resistance mechanisms. Nat Rev Microbiol 2010, 8:317-27.

15. Geller B, Ivey R, Trempy J, Hettinger-Smith B: Cloning of a chromosomal gene required for phage infection of Lactococcus lactis subsp. lactis C2. J Bacteriol 1993, 175:5510-5519.

16. Dupont K, Janzen T, Vogensen FK, Josephsen J, Stuer-Lauridsen B: Identification of Lactococcus lactis genes required for bacteriophage adsorption. Appl Environ Microbiol 2004, 70:5825-32.

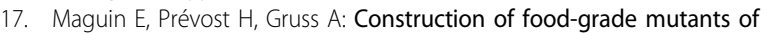
lactic acid bacteria. Lait 1996, 76:139-146.

18. Stuer-Lauridsen B, Janzen T: Bacteriophage resistant bacteria 2006, European Patent Application EP/1838839. 
19. Schouler C, Ehrlich SD, Chopin MC: Sequence and organization of the lactococcal prolate-headed bIL67 phage genome. Microbiology 1994, 140:3061-9.

20. Allison GE, Klaenhammer TR: Phage resistance mechanisms in lactic acid bacteria. Int Dairy Journal 1998, 8:207-226.

21. Janzen $T_{:}$: Unpublished results.

22. O'Connor L, Coffey A, Daly C, Fitzgerald GF: AbiG, a genotypically novel abortive infection mechanism encoded by plasmid $\mathrm{pCl} 750$ of Lactococcus lactis subsp. cremoris UC653. Appl Environ Microbiol 1996, 62:3075-3082.

23. Pedersen $M B$, Jensen $P R$, Janzen T, Nilsson D: Bacteriophage resistance of a $\triangle$ thyA mutant of Lactococcus lactis blocked in DNA replication. App Environ Microbiol 2002, 68:3010-3023.

24. Nilsson D, Janzen T: Method of preventing bacteriophage infection of bacterial cultures 1999, United States Patent Application US/7892585

25. Vaningelgem F, Zamfir M, Mozzi F, Adriany T, Vancanneyt M, Swings J, De Vuyst L: Biodiversity of exopolysaccharides produced by Streptococcus thermophilus strains is reflected in their production and their molecular and functional characteristics. Appl Environ Microbiol 2004, 70:900-12.

26. Senini L, Ricci G, Manachini PL, Mora D: EPS phenotype and genotype in Streptococcus thermophilus strains of dairy origin. Annals of Microbiol 2004, 54:59-71.

27. Almirón-Roig E, Mulholland F, Gasson MJ, Griffin AM: The complete cps gene cluster from Streptococcus thermophilus NCFB 2393 involved in the biosynthesis of a new exopolysaccharide. Microbiology 2000, 146:2793-2802

28. Janzen T, Christiansen DE: Lactic bacterium with modified galactokinase expression for texturizing food products by overexpression of exopolysaccharide 2011., International Patent Application WO/2011/ 026863 .

29. Garrigues C, Johansen E, Crittenden R: Pangenomics-an avenue to improved industrial starter cultures and probiotics. Curr Opin Biotechnol 2013, 24:187-91.

30. Chapot-Chartier M-P, Kulakauskas S: Structure and function of the cell wall of lactic acid bacteria. Microbial Cell Factories 2014, 13(Suppl 1):S9.

31. Strominger JL, Ito $E$, Threnn RH: Competitive inhibition of enzymatic reactions by oxamycin. J Am Chem Soc 1960, 82:998-999.

32. Neuhaus FC, Lynch JL: Studies on the inhibition of D-alanyl-D-alanine synthetase by the antibiotic D-cycloserine. Biochem Biophys Res Commun 1962, 8:377-382.

33. Tipper DJ: Mode of action of $\beta$-lactam antibiotics. Pharmac Ther 1985, 27:1-35

34. Boels IC, Ramos A, Kleerebezem M, de Vos WM: Functional analysis of the Lactococcus lactis galU and galE genes and their impact on sugar nucleotide and exopolysaccharide biosynthesis. Appl Environ Microbiol 2001, 67:3033-3040.

35. Svensson M, Waak E, Svensson U, Rådström P: Metabolically improved exopolysaccharide production by Streptococcus thermophilus and its influence on the rheological properties of fermented milk. Appl Environ Micobiol 2005, 71:6398-6400.

36. Robitaille G, Tremblay A, Moineau S, St-Gelais D, Vadeboncoeur C, Britten M: Fat-free yogurt made using a galactose-positive exopolysaccharideproducing recombinant strain of Streptococcus thermophilus. J Dainy Science 2009, 92:477-482.

37. Pribnow D: Bacteriophage T7 early promoters: nucleotide sequences of two RNA polymerase binding sites. J Mol Biol 1975, 15:419-43.

38. Looijesteijn PJ, Trapet L, de Vries E, Abee T, Hugenholz J: Physiological function of exopolysaccharides produced by Lactococcus lactis. Int I Food Microbiol 2001, 64:71-80.

39. Janzen T, Christiansen DE: Lactic bacterium for texturizing food products selected on basis of phage resistance 2011., International Patent Application WO/2011/092300.

40. Palmer AC, Kishony R: Understanding, predicting and manipulating the genotypic evolution of antibiotic resistance. Nat Rev Genet 2013, 14:243-248.

41. Bennedsen M, Stuer-Lauridsen B, Danielsen M, Johansen E: Screening for antimicrobial resistance genes and virulence factors via genome sequencing. Appl Environ Microbiol 2011, 77:2785-2787.

42. Strøman P, Muller C, Sørensen Kl: Heat shock treatment increases the frequency of loss of an erythromycin resistance-encoding transposable element from the chromosome of Lactobacillus crispatus CHCC3692. Appl Environ Microbiol 2003, 69:7173-7180.

43. Vescovo M, Morelli L, Bottazzi V: Drug resistance plasmids in Lactobacillus acidophilus and Lactobacillus reuteri. Appl Environ Microbiol 1982, 43:50-56.

44. Fons $M$, Hege T, Ladire M, Raibaud P, Ducluzeau R, Maguin E: Isolation and characterization of a plasmid from Lactobacillus fermentum conferring erythromycin resistance. Plasmid 1997, 57:199-203.

45. Danielsen M: Characterization of the tetracycline resistance plasmid pMD5057 from Lactobacillus plantarum 5057 reveals a composite structure. Plasmid 2002, 48:98-103.

46. Huys G, D'Haene K, Swings J: Genetic basis of tetracycline and minocycline resistance in potentially probiotic Lactobacillus plantarum strain CCUG 43738. Antimicrob Agents Chemother 2006, 50:1550-1551.

47. Rosander A, Connolly E, Roos S: Removal of antibiotic resistance genecarrying plasmids from Lactobacillus reuteri ATCC 55730 and characterization of the resulting daughter strain, L. reuteri DSM 17938. Appl Environ Microbiol 2008, 74:6032-6040.

48. Gueimonde M, Florez A, van Hoek A, Stuer-Lauridsen B, Strøman P, ReyesGavilan C, Margolles A: Genetic basis of tetracycline resistance in Bifidobacterium animalis subsp. lactis. Appl Environ Microbiol 2010, 76:3364-3369.

49. Strøman P: New tetracycline-sensitive bifidobacteria strains 2009, European Patent Application EP/2084276.

50. Hugenholtz J: Citrate metabolism in lactis acid bacteria. FEMS Microbiol Rev 1993, 12:165-178.

51. Bartowsky EJ, Henschke PA: The 'buttery' attribute of wine-diacetyldesirability, spoilage and beyond. Int J Food Microbiol 2004, 96:235-52.

52. Mills DA, Rawsthorne H, Parker C, Tamir D, Makarova K: Genomic analysis of Oenococcus oeni PSU-1 and its relevance to winemaking. FEMS Microbiology Reviews 2005, 29:465-475.

53. Kempler GM, McKay LL: Biochemistry and genetics of citrate utilization in Streptococcus lactis ssp. diacetylactis. J Dairy Sci 1981, 64:1527-1539.

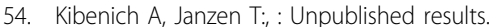

55. Høier E, Janzen T, Rattray F, Sørensen K, Børsting M, Brockmann E, Johansen E: The production, application, and action of lactic cheese starter cultures. In Technology of cheese making.. 2 edition. Blackwell Publishing, Oxford;Law BA and Tamime A 2010:166-192.

56. Monnet C, Mora D, Corrieu G: Glutamine synthesis is essential for growth of Streptococcus thermophilus in milk and is linked to urea catabolism. Appl Environ Microbiol 2005, 71:3376-3378.

57. Carlson M, Janzen T: Production of cottage cheese by using Streptococcus thermophilus. 2010, International Patent Application WO/2011/004012.

58. Sørensen K, Kibenich A, Johansen E: Lactobacillus plantarum cells with improved resistance to high concentrations of ethanol. 2012, International Patent Application WO/2012/172000.

59. Ventura M, O'Flaherty S, Claesson MJ, Turroni F, Klaenhammer TR, van Sinderen D, O'Toole PW: Genome-scale analyses of health-promoting bacteria: probiogenomics. Nat Rev Microbiol 2009, 7:61-71.

60. van Bokhorst-van de Veen $H$, Smelt MJ, Wels $M$, van Hijum SA, de Vos $P$, Kleerebezem M, Bron PA: Genotypic adaptations associated with prolonged persistence of Lactobacillus plantarum in the murine digestive tract. Biotechnol J 2013, 8:895-904.

61. Ruiz L, Margolles A, Sánchez B: Bile resistance mechanisms in Lactobacillus and Bifidobacterium. Front Microbiol 2013, 24:396.

62. Bang Siemsen Jensen N, Johansen AH: Low post-acidifying lactic acid bacteria 2007, International Patent Application WO/2007/147890.

63. Garault P, Le Bars D, Besset C, Monnet M: Three Oligopeptide-binding Proteins Are Involved in the Oligopeptide Transport of Streptococcus thermophilus. J Biol Chem 2002, 277:32-39.

64. Garault P, Faurie J-M, Mengaud J, Druesne A, Quere-Chassang G: AmiDeficient Streptococcus thermophilus strains with reduced postacidification. 2006, International Patent Application WO/2006/042862.

65. Hutkins RW, Ponne C: Lactose uptake driven by galactose efflux in Streptococcus thermophilus: evidence for a galactose-lactose antiporter. Appl Environ Microbiol 1991, 57:941-944.

66. Vaughan EE, van den Bogaard PTC, Catzeddu P, Kuipers OP, de Vos WM: Activation of silent gal genes in the lac-gal regulon of Streptococcus thermophilus. J Bacteriol 2001, 183:1184-1194.

67. De Vin F, Rådström P, Herman L, De Vuyst L: Molecular and biochemical analysis of the galactose phenotype of dairy Streptococcus thermophilus 
strains reveals four different fermentation profiles. Appl Environ Microbiol 2005, 7:3659-3667.

68. Bachmann H, Fischlechner M, Rabbers I, Barfa N, dos Santos FB, Molenaar D, Teusink B: Availability of public goods shapes the evolution of competing metabolic strategies. Proc Nat Acad Sci USA 2013, 110:14302-14307.

69. Johansen E: Genetic engineering (b) Modification of bacteria. In Encyclopedia of Food Microbiology. Academic Press, London:Robinson R, Batt C, and Patel P 1999:917-921.

70. Johansen E: Challenges when transferring technology from Lactococcus laboratory strains to industrial strains. Genet Mol Res 2003, 2:112-116

71. van Pijkeren JP, Britton R: Precision genome engineering in lactic acid bacteria. Microbial Cell Factories 2014, 13(Suppl 1):S10.

72. Jinek M, Chylinski K, Fonfara I, Hauer M, Doudna JA, Charpentier EA Programmable dual-RNA-guided DNA endonuclease in adaptive bacterial immunity. Science 2012, 17:816-21.

doi:10.1186/1475-2859-13-S1-S5

Cite this article as: Derkx et al:: The art of strain improvement of industrial lactic acid bacteria without the use of recombinant DNA technology. Microbial Cell Factories 2014 13(Suppl 1):S5.

\section{Submit your next manuscript to BioMed Central} and take full advantage of:

- Convenient online submission

- Thorough peer review

- No space constraints or color figure charges

- Immediate publication on acceptance

- Inclusion in PubMed, CAS, Scopus and Google Scholar

- Research which is freely available for redistribution

Submit your manuscript at www.biomedcentral.com/submit 